\title{
Biocompatible Hydrogels in Spinal Cord Injury Repair
}

\author{
A. HEJČL ${ }^{1,2,4}$, P. LESNÝ ${ }^{1,2}$, M. PŘÁDNÝ ${ }^{2,3}$, J. MICHÁLEK ${ }^{2,3}$, P. JENDELOVÁ ${ }^{1,2}$, \\ J. ŠTULÍK ${ }^{5}$, E. SYKOVÁ ${ }^{1,2}$
}

${ }^{1}$ Institute of Experimental Medicine, Academy of Sciences of the Czech Republic, Prague, ${ }^{2}$ Center for Cell Therapy and Tissue Repair, Charles University, Second Faculty of Medicine, Prague, ${ }^{3}$ Institute of Macromolecular Chemistry, Academy of Sciences of the Czech Republic, Prague, ${ }^{4}$ Department of Neurosurgery, Masaryk Hospital, Ústí nad Labem, ${ }^{5}$ Department of Spondylosurgery, University Hospital Motol, Prague, Czech Republic

Received February 15, 2008

Accepted April 16, 2008

On-line May 13, 2008

\section{Summary}

Spinal cord injury results in a permanent neurological deficit due to tissue damage. Such a lesion is a barrier for "communication" between the brain and peripheral tissues, effectors as well as receptors. One of the primary goals of tissue engineering is to bridge the spinal cord injury and re-establish the damaged connections. Hydrogels are biocompatible implants used in spinal cord injury repair. They can create a permissive environment and bridge the lesion cavities by providing a scaffold for the regeneration of neurons and their axons, glia and other tissue elements. The advantage of using artificial materials is the possibility to modify their physical and chemical properties in order to develop the best implant suitable for spinal cord injury repair. As a result, several types of hydrogels have been tested in experimental studies so far. We review our work that has been done during the last 5 years with various types of hydrogels and their applications in experimental spinal cord injury repair.

\section{Key words}

Spinal cord injury • Hydrogel • Tissue engineering • Stem cells • Regenerative medicine

\section{Corresponding author}

E. Syková, Institute of Experimental Medicine AS CR, Vídeňská 1083, 14220 Prague 4, Czech Republic. Fax: + 420-241062782. E-mail: sykova@biomed.cas.cz

\section{Spinal cord injury}

The leading causes of spinal cord injury are motor-vehicle accidents, accounting for almost half of all cases (47 \%), followed by sports-related accidents (24\%), falls (12\%), and violence injuries (7\%) (http://www.spinalcord.uab.edu, Spinal Cord Injury Information Network). In the USA alone, around 11.000 individuals suffer from a spinal cord injury (SCI) each year (DeVivo et al. 2002). In clinical practice most spinal cord injuries can be divided into two groups. In the first group are young individuals who sustained their injury from a motor vehicle accident or, especially during the summer months, diving into shallow water. The second group consists of older individuals with cervical spinal stenosis caused mostly by spondylosis. These individuals can sustain a minor trauma causing spinal cord contusion without any vertebral fracture. In some countries there is also a third group, which consists of people with gunshot wounds. The neurological status of the patient is clinically evaluated using the Frankel score or the American Spinal Cord Association (ASIA) scale. Incomplete tetraplegia is present in $34.1 \%$ of cases, followed by complete paraplegia (23\%), complete tetraplegia (18.3\%), and incomplete paraplegia (18.5\%). Further, sensory changes and autonomic dysfunction are equally important.

The spinal cord trauma is usually caused by spinal cord compression due to a bone fragment or a 
vertebral disc dislocation or dislocation of spinal vertebral motion segments. The morphology varies with the force of the spinal cord compression, the duration of compression, the displacement of the spinal cord, the acceleration of the impacting forces, and the kinetic energy absorbed at the time of spinal cord impact. The majority of spinal cord injuries do not comprise a spinal cord transection (Bunge et al. 1993). There are three phases of SCI response that occur after injury (Tator 1995, 1996, 1998). Upon primary injury, there is immediate mechanical damage to neural and other soft tissues, including endothelial cells of the vasculature. This phase is associated with hemorrhage, localized edema, loss of microcirculation by thrombosis, vasospasm and mechanical damage, and loss of vascular autoregulation, all of which further exacerbate the neural injury. In the secondary phase (which occurs over a time course of minutes to weeks) the devastating effect of ischemic cellular death, ionic shifts, and edema continue from the acute phase. Inflammatory cells invade the spinal cord parenchyma. Apoptosis occurs and involves reactive gliosis that includes the increased expression of glial fibrillary acidic protein (GFAP) and astrocytic proliferation. Finally, in the chronic phase, which occurs over a time course of days to years, apoptosis continues, together with scarring, demyelination and cyst formation (Hulsebosch 2002). A glial scar develops in days to weeks after the injury, and glial hypertrophy peaks at 2-3 weeks after the injury.

Spinal cord injury thus results in tissue damage forming a "communication barrier" between the cranial and the caudal stump. Kwon et al. (2005) characterized three types of experimental models most commonly used in spinal cord injury studies: transection, compression and contusion. While transection is amenable to anatomical demonstrations of regeneration, it does not reflect the type of spinal cord injury most often seen in clinical practice. Compression and contusion models, on the other hand, resemble human spinal cord injuries quite well, but do not allow precise control of the exact location and extent of the lesion. In our experiments we mainly used two types of spinal cord injury: hemisection/ transection as a model of acute SCI and a ballooninduced compression lesion for modeling chronic SCI, which does not require a laminectomy and therefore best mimics the clinical situation (Vanický et al. 2001, Urdzíková et al. 2006).

Many natural and artificial materials have been used in spinal cord injury repair. Natural materials include a collagen or an alginate hydrogel. Implantation of a freeze-dried alginate sponge into the complete spinal cord transection cavity of infant or young rats stimulated not only the ingrowth of numerous myelinated and unmyelinated fibres into the hydrogel (Kataoka et al. 2001, Suzuki et al. 1999), but also functional projections across and beyond the gap, with the formation of synaptic connections with host neurons on the other side (Suzuki et al. 2002). An artificial substrate for bridging spinal cord lesions should ideally have a structure that is easily modifiable, can serve as a scaffold for matrix molecules and acellular implants, is immunologically inert and, finally, is resorbable (Jendelová et al. 2005, Novikova et al. 2003). Synthetic biodegradable implants include polyethylene glycol, fibrin glue, or the commercially produced Matrigel (Becton Dickinson Labware, Bedford, MA, USA). After inserting a poly(lactic-co-glycolic acid) (PLGA) scaffold seeded with neural stem cells into a SCI cavity, numerous regenerating axons were found in the graft as well as in the spinal cord caudal to the injury. Both cellular and acellular implants reduced cavitation and promoted functional recovery, which persisted up to 1 year after the injury (Lavik et al. 2002).

The advantage of using artificial implants is that we can modify their properties in a controlled fashion. Several groups have attempted to create oriented pores in order to promote directed axonal regeneration (Dalton et al. 2002, Prang et al. 2006). Prang showed that after implanting a scaffold with oriented pores in an acute spinal cord injury, these alginate-based hydrogels induced directed axonal regeneration. Even further, seeding adult neural stem cells in the hydrogel implant promoted cellcontact-mediated axonal regeneration in vitro. Another important factor is the mechanical stability of the hydrogel. Marchand et al. (1993) showed that extending the stability of a collagen scaffold for more than 2-3 months by cross-linking improved the mechanical properties of the matrix and ensured axonal regeneration over a 6 month period (Marchand et al. 1993). This is especially important in light of the efforts to fabricate biodegradable implants. The surface of scaffolds can also be modified to improve their biological properties. Modifying an agarose gel with the extracellular protein laminin or nerve growth factor (NGF)-releasing microcylinders significantly enhanced axonal growth from dorsal root ganglia (Yu et al. 1999).

We have developed several types of biocompatible implants, including resorbable and nonresorbable hydrogels and implants based on nanofibres 

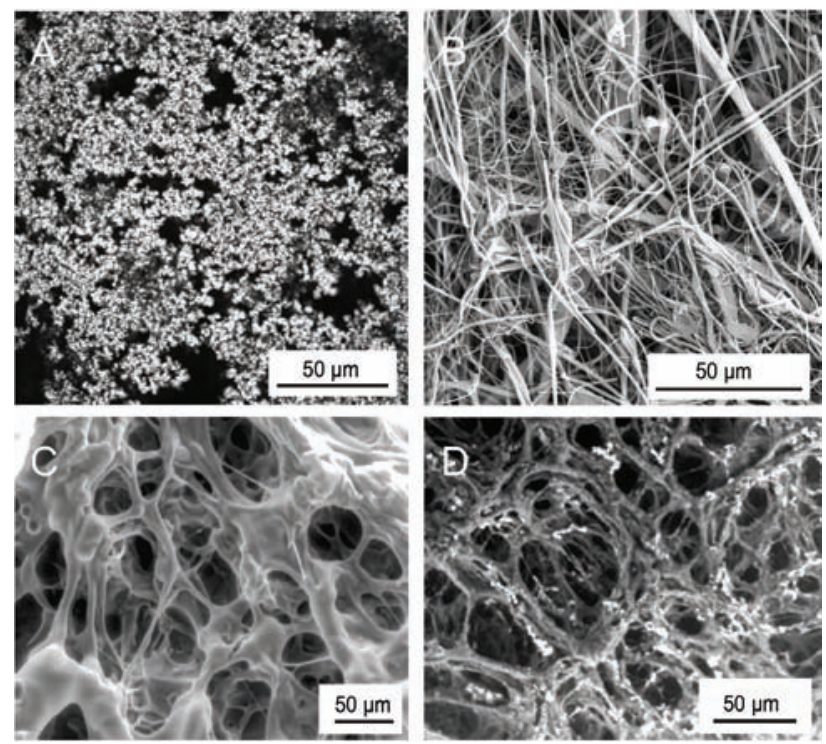

Fig. 1. Four types of hydrogels implanted in experimental $\mathrm{SCI}$ in our Centre. A. HPMA-RGD hydrogel. B. Nanofibre scaffold. C. HEMA hydrogel. D. Biodegradable HEMA-based hydrogel, partially degraded after 2 days.

that have been applied in experimental spinal cord injury repair as scaffolds for nervous tissue regeneration as well as stem cell carriers.

\section{Hydrogels}

Hydrogels are crosslinked hydrophilic polymers. They have a high water content (up to $98 \%$ ) and can have a porous structure with a pore size mostly between 10-100 $\mu \mathrm{m}$ (macroporous hydrogels) (Bakshi et al. 2004, Lesný et al. 2006, Prang et al. 2006, Přádný et al. 2003, 2005, 2006, Woerly et al. 1992, 1999). The history of the use of hydrogels in medicine is long (Wichterle and Lim 1960), and their importance has steadily increased. In SCI repair they serve as a bridge for axonal growth across the lesion cavities. They also prevent scarring and thus create a permissive environment for tissue regeneration. With their three-dimensional porous structure, they provide an acellular mechanical framework for the ingrowth of supportive tissue and, together with other strategies supporting regeneration (e.g. growth factors, stem cells), may contribute to regeneration after SCI. In particular, some of their properties make these scaffolds the most promising for neural tissue engineering: 1) they can be synthesized and produced in large quantities; 2) their chemical and physical properties can be easily modified and prepared for immediate use in surgery theatres; 3 ) the diffusion parameters within implanted hydrogels attain values similar to developing neural tissue (Woerly et al.
1999); 4) their tissue reconstruction properties may be improved using stem cells, neurotrophins or signaling sequences (Loh et al. 2001, Teng et al. 2002, Woerly et al. 2001a,b).

\section{Hydrogels based on HEMA and HPMA}

Hydrogels based on poly(2-hydroxyethyl methacrylate) (PHEMA) and poly $N$-(2-hydroxypropyl)methacrylamide (PHPMA) belong to a group of synthetic highly biocompatible polymers. Our previous studies showed that their viscoelastic properties are similar to those of neural tissue (Woerly et al. 1999, Lesný et al. 2002, Hejčl et al. 2008). HEMA-based hydrogels have been used by several SCI research groups including ours (Dalton et al. 2002, Bakshi et al. 2004, Lesný et al. 2002). Modifying the surface charge of the hydrogel using copolymers and polyelectrolyte complexes further modifies its mechanical properties or the water content in an equilibrium-swollen state (Prádný et al. 2005). The pronounced ingrowth of connective tissue elements as well as nervous tissue elements, such as NF-160-positive neurofilaments and Schwann cell projections, was found in positively charged HEMA copolymers.

Another approach to improving axonal regeneration is adjusting the adhesion properties of the hydrogels. Woerly et al. (1995) studied a PHPMA hydrogel modified with an attached oligopeptide sequence (RGD). The PHPMA-RGD implant showed stronger adhesion to the host tissue and promoted the ingrowth and spread of astrocytes and neurofilaments inside the hydrogel. The adhesion properties of hydrogels may also be modified using various functional groups with a positive or a negative charge (Lesný et al. 2006). Dorsal root ganglia (DRG) cultured on an agarose hydrogel with a covalently bound chitosan (polycationic polysaccharide) showed a significant increase in the length of regenerating axons (Dillon et al. 1998). Combining scaffold implantation with neurotrophic factors or stem cell treatment may lead to improved results in regenerating SCI. Loh et al. (2001) found that modifying a PHPMA-RGD hydrogel with either brainderived neurotrophic factor (BDNF) or ciliary neurotrophic factor (CNTF) significantly increases the ingrowth of axons into the implant compared to unmodified hydrogels (Yu et al. 1999, Loh et al. 2001). Tsai et al. (2006) used a PHEMA-co-methyl methacrylate hydrogel with a combination of various matrices and growth factors in a spinal cord transection. In this study 
they showed that specific combinations may lead to selective improvement in the regeneration of selected brainstem tracts. We have used both types of hydrogels in brain injury and spinal cord injury repair (Lesný et al. 2002, Woerly et al. 1999, Přádný et al. 2006, Hejčl et al. 2008).

Both types (HEMA- or HPMA-based) of hydrogels were employed in an in vivo study in spinal cord injury; a hemisection was performed at the Th8 level, and the hydrogel was trimmed to fit the lesion site properly. An implant with a size of $2 \times 2 \times 2 \mathrm{~mm}$ was inserted inside the cavity (Fig. 2A). The spinal cords with hydrogel implants were evaluated 2, 4 and 8 weeks and, in the case of HEMA-based hydrogels, also 6 months after spinal cord injury. On the macroscopic scale, the hydrogels adhered very well to the lesion site forming a firm bridge across the cavity (Fig. 2B). Histologically, both hydrogels bridged the cavity with minimal glial scarring or pseudocyst formation. The HEMA-based hydrogels were stable even 6 months after implantation. Two weeks after spinal cord hemisection, the hydrogels were infiltrated with connective tissue throughout both the peripheral and central parts of the 3D implant (Fig. 2C). Blood vessels crossed the hydrogel-spinal cord border and infiltrated the pores (Fig. 2D). A progressive ingrowth of axons in a time-dependent manner was observed. While two weeks after spinal cord injury axons infiltrated only the border zones of the implant (Fig. 2E), eight weeks after injury the hydrogel implant was also infiltrated in the central parts (Fig. 2F). Regenerating axons were clearly distinguished using GAP-43 staining (Fig. 2G). Schwann cells grew from the CNS-PNS transition zone (spinal cord - spinal root), i.e. from the cranial and caudal lateral corners of the lesion into the pores of the hydrogel (Fig. 2H). In the hydrogel, Schwann cells grew along the axons, which may be important for the process of myelination (Fig. 2I). In both types of hydrogels astrocytic processes infiltrated only the border zones (Fig. 2J).

\section{Hydrogels with positive or negative charges}

Various modifications of biomaterials used in tissue engineering have been investigated, including modifications of the surface charge. The influence of surface charge on cell growth has been studied since 1975 in order to provide better cultivation conditions in culture flasks. It is now well understood that many cell types, including neuroblastoma cells (Soekarno et al. 1993), adhere better to positively charged surfaces. Enhanced attachment and suppressed spreading of mesenchymal stem cells (MSCs) were observed on a positively charged indium tin oxide (ITO) pattern-coated substrate (Qiu et al. 1998).

We studied the growth of MSCs assessed in vitro in macroporous hydrogels based on HEMA copolymers with different electric charges (Lesný et al. 2006). Copolymers of HEMA with sodium methacrylate (MANa) carried a negative electric charge, copolymers of HEMA with [2-(methacryloyloxy)ethyl] trimethylammonium chloride (MOETACl) carried a positive electric charge and terpolymers of HEMA, MA and MOETACl carried both positive and negative electric charges. The charges in the polyelectrolyte complexes (PEC) were shielded by counter-ions. The hydrogels had similar porosities, based on a comparison of their diffusion parameters for small cations as measured by the real-time tetramethylammonium iontophoretic method of diffusion analysis (Syková et al. 2004, Nicholson and Syková 1998, Woerly et al. 1999, Prokopová-Kubinová et al. 2001). The cellular density was lowest on the first day of incubation and then increased on the 2nd and 7 th days, indicating cellular growth within the hydrogels. The highest cellular density was observed on the 7th day of cultivation followed by a decrease, reaching a steady state on the 14th and 28th days of cultivation. MSCs were most abundant on the hydrogel with a positive charge only (copolymer of HEMA with MOETACl). In hydrogels containing positive charges, MSCs were distributed predominantly in the peripheral region compared to hydrogels with a negative or no charge. This distribution is probably mediated by the adsorption of serum macromolecules onto the positively charged quaternary ammonium groups. This adsorption increases the attachment of MSCs to the surface of the hydrogel, leading to enhanced cell attachment and suppressed cell migration.

In another study, we evaluated the ingrowth of neuronal tissue elements in hydrogels with different charges in vivo in a hemisection model of spinal cord injury (Lesný et al. 2006). All four types of hydrogels described above were implanted to bridge a hemisection cavity at the Th8 level. Histological evaluation was performed 4 weeks after the implantation. In the negatively charged hydrogels (PHEMA/MANa), there was only a small amount of tissue, while in the positively charged hydrogels (PHEMA/MOETACl), the ingrowing tissue filled all the pores within the hydrogel 
(Fig. 2K, L). There was also a difference in the way the neurofilaments infiltrated the pores of the hydrogels. While in the negatively charged hydrogels axons grew in close contact with the surface of the hydrogel, in the positively charged hydrogels, where the cell count was higher, the axons grew in the pores of the hydrogel. The ingrowth of neurofilaments and astrocytic processes was evaluated. Neurofilaments infiltrated the border zones and the peripheral part of the hydrogel in all four groups. Except for the polymer with polyelectrolyte complexes, neurofilaments also infiltrated the central parts of the hydrogels, most abundantly in the copolymers with a positive charge. On the other hand, astrocytic processes infiltrated the border zones (not further than $20 \mu \mathrm{m}$ ) of the hydrogels with negative charges or PEC. Minimal or no astrocytes were found in hydrogels with positive charges.

\section{Biodegradable hydrogels}

Biodegradable hydrogels represent a significant group of biomaterials. The major advantage of using biodegradable hydrogels is that they can provide a scaffold for the ingrowth of neural tissue elements and later, after the cavity is bridged with regenerated tissue, they would degrade. However, there are still some limits to this approach; the optimal degradation rate, for example, has not been determined. Also, the degradation products should be considered since they may be toxic to the nervous tissue.

Four biodegradable macroporous hydrogels were prepared by cross-linking radical polymerization of the monomers HPMA and 2-ethoxyethyl methacrylate (EOEMA). The monomer compositions of the hydrogels were (by weight): 10, 21, 29 or $43 \%$ EOEMA in a mixture with HPMA (relative to the monomers) with degradation periods increasing in the same order: 7, 9, 34 days and non-biodegradable (Jendelová et al. 2005, Přádný et al. 2003, 2005). These 4 types of hydrogels were implanted in a hemisection model of spinal cord injury and evaluated 1 month after surgery. All of the implanted hydrogels were well tolerated; we did not observe a foreign-body reaction. After 28 days, none of the implanted hydrogels was fully degraded in vivo. The size (volume) of the peripheral zone of the degraded hydrogel was dependent on the degradation rate of the hydrogel. The largest peripheral zone of degraded hydrogel was observed in the hydrogels biodegradable within 7 days (Fig. 2M).
The size of this zone decreased with the increase of the hydrogel degradation time. The $43 \%$ EOEMA hydrogel did not degrade and contained a moderate number of cells growing on the surfaces of the hydrogel. The hydrogels degraded from the interface with the spinal cord towards the central part of the hydrogel. The hydrogels were resorbed by macrophages and replaced by newly formed tissue containing connective tissue elements, blood vessels, astrocytic processes and neurofilaments. The central part of the hydrogels consisted of amorphous matter (Fig. 2N), where mostly the ingrowth of connective tissue and capillaries was observed.

\section{Spinal cord transection treated with delayed hydrogel implantation}

One of the most important aspects in spinal cord injury repair is timing. Spinal cord injury is a dynamic process, as described above. During the first days after injury, the lesion is dominated by edema, hemorrhage, inflammation, demyelination, neuronal loss and axonal damage. These conditions are not favorable for hydrogel implantation. Glial scarring, on the other hand, reaches a peak of hypertrophy two to three weeks after the injury, and progressive pseudocysts develop even later. Another reason for delaying the implantation procedure is that the neurological status of a SCI patient is not settled until about 3 weeks or more following the injury. The basis for early recovery is the resolution of edema and the return of function in axons that were only partially injured (Kakulas 2004). Implanting a hydrogel is an invasive procedure inevitably resulting in some degree of tissue damage. Manipulating the tissue may interfere with early recovery and aggravate the final clinical status of the patient. We can therefore expect that hydrogel implantation in clinical settings will be performed with some delay after the primary insult when the lesion site is demarcated and the neurological status of the patient stabilized.

Delayed treatment for spinal cord injury has already proven effective in some cases. (Coumans et al. 2001, Woerly et al. 2001a,b) Coumans et al. (2001) found that using embryonic spinal cord tissue may improve histological and functional outcome even 2 or 4 weeks after spinal cord transection. Woerly et al. (2001a,b) showed an improvement in behavioral and histological outcomes when NeuroGel ${ }^{\mathrm{TM}}$ was implanted 3 months after a contusion lesion. 

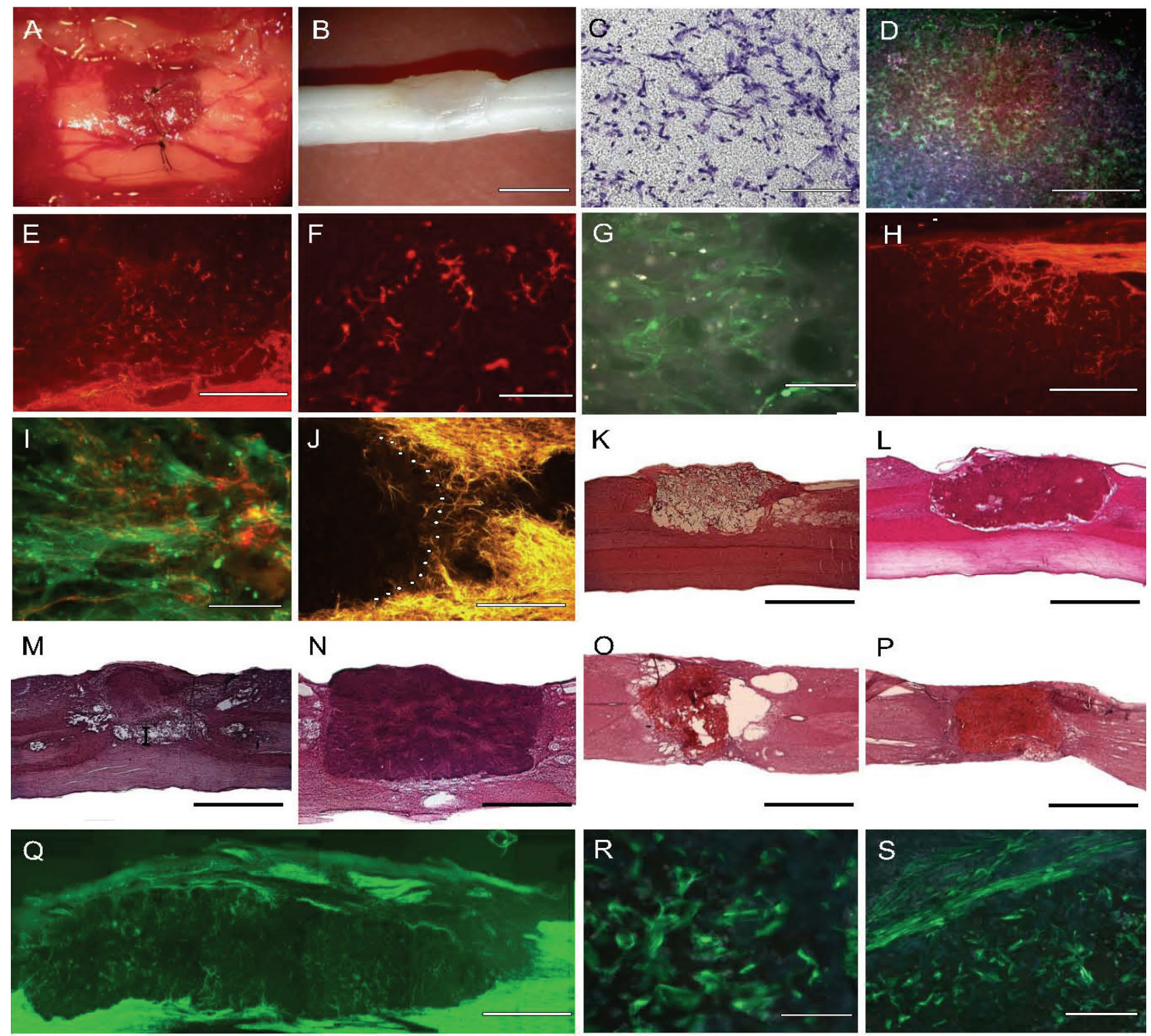

Fig. 2. A. HPMA-RGD hydrogel implanted in a hemisection lesion. Laminectomy was performed at the Th8 level. The dura was cut and a $2 \mathrm{~mm}$ segment in the right half of the spinal cord was dissected out. The hydrogel was trimmed to adapt to the cavity. The dura was sutured to avoid scarring from the extradural region. B. The hydrogel implanted inside a hemisection cavity one month after implantation. It adhered well to the spinal cord (scalebar $=2 \mathrm{~mm}$ ). C. Detail of the central part of the positively charged HEMA hydrogel. The pores of the scaffold are infiltrated with cells (CV staining, scalebar $=100 \mu \mathrm{m})$. D. Regenerating blood vessels infiltrating the pores of the HPMA-RGD hydrogel implant two weeks after implantation (RECA staining, scalebar $=250 \mu m$ ). E, F. Two weeks after the HPMA-RGD implantation inside a hemisection. Neurofilaments were found mostly in the peripheral parts of the hydrogel, while four weeks after implantation the central part of the hydrogel was infiltrated as well (NF160 staining, scalebar $_{G}=250 \mu \mathrm{m}$, scalebar $_{\mathrm{H}}=$ $100 \mu \mathrm{m})$. G. Regenerating neurofilaments on the HPMA-RGD hydrogel-tissue interface (GAP-43 staining, scalebar $=50 \mu \mathrm{m})$. $\mathbf{H}$. Schwann cells grew from the spinal root entry zone into the HPMA-RGD hydrogel (p75 staining, scalebar $=250 \mu \mathrm{m})$. I. Within the implanted hydrogel scaffold Schwann cells grew along the regenerating neurofilaments (NF160-p75 staining, scalebar $=100 \mu m$ ). J. Astrocytes only rarely crossed the border zones (white dotted line) of the HPMA-RGD hydrogel (GFAP staining, scalebar $=250 \mu \mathrm{m}$ ). K-L. Negatively (K) and positively (L) charged HEMA hydrogels bridging a hemisection cavity. Fewer cells grew inside the negatively charged hydrogel compared to the positively one. M. Biodegradable HPMA hydrogel with a degradation time of 7 days. The obliterated hydrogel is surrounded by a zone where the polymer has already degraded and newly formed tissue has appeared (black bar) (HE staining, scalebar $=1 \mathrm{~mm})$. $\mathbf{N}$. Biodegradable HPMA hydrogel with a degradation time of 34 days. The hydrogel is minimally degraded with a large central part consisting of amorphous matter infiltrated with connective tissue and capillaries (HE staining, scalebar = $1 \mathrm{~mm}$ ). $\mathbf{0}, \mathbf{P}$. Positively charged HEMA hydrogels were implanted either immediately $(O)$ or after a one week delay $(P)$ after the spinal cord transection at the Th8 level. It is apparent that delayed implantation was associated with a reduction in the size of pseudocysts (HE staining, scalebar $=1 \mathrm{~mm}$ ). Q. HPMA-RGD hydrogel implanted inside a balloon compression spinal cord injury lesion 5 weeks after the injury. The hydrogel formed a bridge across the cavity and provided a scaffold for regenerating neurofilaments (NF160 staining, scalebar $=1 \mathrm{~mm})$. R, S. HPMA-RGD hydrogel seeded with GFP-positive mesenchymal stem cells and implanted into a hemisection cavity. Two weeks after implantation the stem cells were found not only in the hydrogel (R) but they also infiltrated the spinal cord tissue surrounding the lesion (S) (GFP, scalebar $=25 \mu \mathrm{m})$. 
In one of our studies we examined whether delayed implantation can successfully bridge a transection cavity compared with immediate implantation (Hejčl et al. 2008). We performed a complete spinal cord transection by excising a 1-2 mm segment of the spinal cord. We implanted a positively charged HEMA-based hydrogel inside the cavity either immediately or 1 week after the injury. A third group of animals was left untreated and served as a control group. The spinal cords were evaluated 90 days after the surgery. Three months after the spinal cord transection the lesion site was dominated by a major pseudocystic cavity in control animals. In the treated groups of animals the hydrogel implants adhered well to the spinal cord tissue. Histological evaluation showed ingrowth of regenerating axons, Schwann cell projections, blood vessels and connective tissue elements into the hydrogels, while astrocytes infiltrated only the border zones. Morphometric analysis of the lesions showed a statistically significant reduction in pseudocyst volume in the treated animals compared with controls and in the delayed treatment group compared with the immediate treatment group. In conclusion, delayed hydrogel implantation can bridge a posttraumatic spinal cord cavity more effectively than immediate reconstructive surgery. This can be very important for future clinical practice as this may provide a therapeutic window of opportunity.

\section{PHPMA-RGD hydrogels in chronic spinal cord injury repair}

Spinal cord contusion and compression result in the formation of a cavity that forms a barrier for axonal regeneration. Pseudocystic cavities, which develop in necrotic regions, are formed by a thin astrogliotic lining filled with extracellular fluid and macrophages. Such a cavity does not provide any scaffold for nervous tissue regeneration. Thus, providing a 3-dimensional scaffold could serve as a rational therapy for the reconstruction of a spinal cord lesion.

A balloon compression lesion is a simple and reproducible model of SCI (Vanický et al. 2001, Urdzíková et al. 2006). It is a reliable and reproducible model also used for behavioral evaluation in experimental spinal cord therapy. A 2-French Fogarty catheter is inserted into the dorsal epidural space through a hole in the Th10 vertebral arch. A complete spinal cord lesion is made by balloon inflation (volume $15 \mu \mathrm{l}$ ) at the Th8-Th9 spinal level. Inflation for 5 min produces paraplegia
[Beattie-Basso-Bresnahan (BBB) score 0] immediately after the lesion. Five weeks after the injury, rats with a moderate spinal cord lesion reach a BBB score of 7-8.

Five weeks after SCI, a Th8-Th9 laminectomy was performed. It was very important to identify the epicenter of the lesion with the pseudocyst. The surface of the spinal cord showed discreet signs of hemorrhage and slight atrophy. In some cases, the pseudocyst cavity was apparent through the dorsal aspect of the spinal cord. The dura mater was opened above the lesion. A sagittal or a parasagittal incision was performed, the cavity was opened and the cellular debris was removed. A PHPMARGD hydrogel was trimmed to the shape and size of the cavity and implanted inside. The dura mater was sutured with $10 / 0$ thread to avoid extradural tissue scarring invading the lesion site. Muscles and skin were sutured in anatomical layers. The spinal cords were histologically evaluated 2, 4 and 8 weeks after the hydrogel implantation. The pseudocyst was bridged completely with the hydrogel (Fig. 2Q). The hydrogel was already infiltrated with connective tissue elements two weeks after implantation. Further, neural processes and Schwann cells were present in the border zones as well as in the center of the hydrogel as early as two weeks after implantation. In accordance with our other experiments, a minimal number of astrocytes invaded the border zones of the hydrogels. No astrocytic processes grew to the center of the implants.

\section{Combining hydrogel bridging with cell therapy}

Bone marrow stem cells have been used in clinical practice for many years for patients with hematological diseases. Stem cell biology has developed in the last decade into a major part of neuroscience research. In recent years mesenchymal stem cells (MSCs) have been used in experimental therapies in many CNS disorders, including spinal cord injury (Prockop 1997, Jendelová et al. 2004, Syková and Jendelová 2005, Nandoe et al. 2006, Syková et al. 2006a,b, Syková and Jendelová 2006, Urdzíková et al. 2006, Syková and Jendelová 2007a,b). Mesenchymal stem cells are pluripotent progenitor cells that have the capability to migrate and exhibit site-dependent differentiation in response to environmental signals. In culture they can differentiate into osteoblasts, chondrocytes, adipocytes and myoblasts (Pittenger et al. 1999, Prockop 1997). After transplantation into the brain, MSCs respond to 
intrinsic signals and may rescue partly damaged cells and accelerate regeneration by the production of growth factors (Kopen et al. 1999, Brazelton et al. 2000, Urdzíková et al. 2006, Syková et Jendelová et al. 2006). The use of MSCs in cell therapies may have some advantages over the use of other sources of cells: they are relatively easy to isolate, they may be used in autologous transplantation protocols and bone marrow as a source of cells has been already approved for the treatment of hematopoietic diseases. In a clinical study initiated in 2003 at the Motol Teaching Hospital in Prague, we investigated the transplantation of unmanipulated autologous bone marrow in patients with a transversal spinal cord injury with respect to safety, therapeutic time window, implantation strategy, method of administration, and functional improvement (Syková et al. 2006a,b). Our case study shows that the implantation of autologous bone marrow cells appears to be safe. Further, our results show that transplantation within a therapeutic window of 3-4 weeks following injury, which is in agreement with studies in rodents, may play an important role in stem cell SCI treatment. Although functional improvement has been found in some patients, a larger and more homogenous group needs to be studied and compared to a control group before a beneficial effect can be demonstrated.

It was shown that transplanted human MSCs have the ability to increase the expression of growth and trophic factors in the ischemic rat brain (Chen et al. 2002). Recently, several attempts were made to create cell-polymer constructs with genetically engineered cells (Loh et al. 2001) or with stem cells (Li et al. 2002) to provide a biohybrid system for tissue bridging in cases where a large tissue defect exists. In our own experimental study, we compared acute treatment in rats with SCI with three different modalities of therapy: an intravenous injection of mesenchymal stem cells (MSCs), an injection of a freshly prepared mononuclear fraction of bone marrow cells (BMCs) or bone marrow cell mobilization induced by granulocyte colony stimulating factor (G-CSF). Animals with SCI treated with MSCs, BMCs or G-CSF had higher BBB scores and better recovery of hind limb sensitivity than controls injected with saline. Morphometric measurements showed an increase in the spared white matter (Urdzíková et al. 2006). Therefore, it is rational to combine hydrogel implantation and stem cell therapy.

We implanted three types of hydrogels in spinal cord injury. Two of these hydrogels were based on
HPMA and the third one was based on HEMA. Hemisection at the level of Th8-9 served as a model of spinal cord injury. All three hydrogels were trimmed to small cubes with a volume of $8 \mathrm{~mm}^{3}(2 \times 2 \times 2 \mathrm{~mm})$. Before implantation, the hydrogels were seeded with 2 million green fluorescent protein-positive (GFP) MSCs. The hydrogels were implanted inside a hemisection cavity immediately after injury. Two and four weeks after spinal cord injury, the spinal cords were histologically evaluated. Mesenchymal stem cells were found more abundantly in the HPMA-based hydrogels compared to the HEMA-based hydrogels. Most of the cells resided in the pores of the hydrogels (Fig. 2R); however, some cells migrated and infiltrated the border zones of the spinal cord (Fig. 2S) (Hejčl et al. 2007). Using this approach, hydrogels can serve as carriers for delivering stem cells to the site of an injury.

\section{Utilization of nanofibre scaffolds}

Nanofibres, either self-assembled or created by the electrospinning process, form a three-dimensional network, with morphology and fiber diameters in a range comparable with those found in the extracellular matrix of nervous tissue (Vasita and Katti 2006). Therefore, nanofibrous scaffolds can be utilized to provide a better environment for neural cell attachment, migration, proliferation and differentiation when compared with traditional scaffolds (Martins et al. 2007). Carbon nanofibres have positive selection properties on neural cells and negative on astrocytes, which leads to decreased glial scar formation (McKenzie et al. 2004). The neurons adhere and can be cultivated on the poly(l-lactic acid) nanofibres and they tend to grow along the fibres (Yang et al. 2005). This led to the study of composite implants into the spinal cord containing the parallel nanofibres and cultured human embryonic spinal cord cells (Rochkind et al. 2006), in which all four implanted animals revealed in 3 months partial recovery of function in one or two limbs. Nanofibres can be also prepared from biocompatible polymers. The advantage of polymer nanofibres is their high biocompatibility; many cell types can be cultivated on the surface of nanofibre layers (Lesný et al. 2007). After implantation into the spinal cord, implants based on layers of polymer nanofibres integrate into the spinal cord and allow the ingrowth of connective tissue, blood vessels and neural cell processes. The extent of the ingrowth is dependent on the spatial orientation of the nanofibre layers (Přádný et al. 2007). The results show 
that the use of nanofibres can be a suitable strategy for neural tissue reconstruction in the spinal cord.

\section{Future perspectives}

Hydrogels used in spinal cord injury repair are still being developed and improved. There are several directions in hydrogel research. Hydrogels are threedimensional macroporous structures with pores of not only different sizes, but also different directions. However, spinal cord columns lead afferent and efferent spinal cord tracts in the cranio-caudal direction or vice versa. Therefore, hydrogels with pores predominantly in a cranio-caudal orientation are being developed. Further, lining the pores of hydrogels with cell-adhesion promoting substances, such as laminin or fibronectin, can further improve tissue regeneration.

Another important factor is the phase of the implant. All of the hydrogels that have been tested were in a solid phase. Bridging a pseudocyst with a solid hydrogel requires a surgical procedure that causes damage to the spinal cord tissue. Such damage should be minimized. Therefore, hydrogels in a liquid phase that could be injected into a lesion site would clearly minimize such damage. Conversely, the properties of such an implant could be more difficult to control in the lesion.

Most importantly, spinal cord injury therapy requires a combined treatment approach. The advantage of hydrogels in spinal cord injury repair is that they can not only serve as a bridge, but also as a carrier of stem cells, neurotrophic factors, inhibitory molecules or enzymes that could digest deposits of extracellular matrix, e.g. chondroitin sulfate proteoglycans. In the future a multidisciplinary approach will result in the development of a successful strategy for SCI repair using hydrogel implants in human medicine.

\section{Conflict of Interest}

There is no conflict of interest.

\section{Acknowledgements}

We thank James Dutt for reading of the manuscript. This work was supported by the following grants: AVOZ50390703 from the Academy of Sciences of the Czech Republic, LC554 from the Ministry of Education of the Czech Republic, GACR309/06/1246 from the Czech Science Foundation, 1A8697-5 from the Ministry of Health of the Czech Republic, and the EC FP6 project RESCUE (LSHB-CT-2005-518233).

\section{References}

BAKSHI A, FISHER O, DAGCI T, HIMES BT, FISCHER I, LOWMAN A: Mechanically engineered hydrogel scaffolds for axonal growth and angiogenesis after transplantation in spinal cord injury. J Neurosurg Spine 1: 322-329, 2004.

BRAZELTON TR, ROSSI FM, KESHET GI, BLAU HM: From marrow to brain: expression of neuronal phenotypes in adult mice. Science 290: 1775-1779, 2000.

BUNGE RP, PUCKETT WR, BECERRA JL, MARCILLO A, QUENCER RM: Observations on the pathology of human spinal cord injury: A review and classification of 22 new cases with details from a case of chronic cord compression with extensive focal demyelination. Adv Neurol 59: 75-89, 1993.

CHEN X, LI Y, WANG L, KATAKOWSKI M, ZHANG L, CHEN J, XU Y, GAUTAM SC, CHOPP M: Ischemic rat brain extracts induce human marrow stromal cell growth factor production. Neuropathology 22: 275-279, 2002.

COUMANS JV, LIN TT, DAI HN, MACARTHUR L, MCATEE M, NASH C, BREGMAN BS: Axonal regeneration and functional recovery after complete spinal cord transection in rats by delayed treatment with transplants and neurotrophins. J Neurosci 21: 9334-9344, 2001.

DALTON PD, FLYNN L, SHOICHET MS: Manufacture of poly(2-hydroxyethyl methacrylate-co-methyl methacrylate) hydrogel tubes for use as nerve guidance channels. Biomaterials 23: 3843-3851, 2002.

DE VIVO MJ, GO BK, JACKSON AB: Overview of the national spinal cord injury statistical center database. $J$ Spinal Cord Med 25: 335-338, 2002.

DILLON GP, YU X, SRIDHARAN A, RANIERI JP, BELLAMKONDA RV: The influence of physical structure and charge on neurite extension in a 3D hydrogel scaffold. J Biomater Sci Polymed Ed 9: 1049-1069, 1998. 
HEJČL A, ŠEDÝ J, LESNÝ P, AMEMORI T, BURIAN M, HÁJEK M, KRUMBHOLCOVÁ E, PŘÁDNÝ M, MICHÁLEK J, JENDELOVÁ P, SYKOVÁ E: Biocompatible hydrogels in spinal cord injury repair. In: Neuroscience 2007. San Diego, USA, 2007.

HEJČL A, URDZÍKOVÁ L, ŠEDÝ J, LESNÝ P, PŘÁDNÝ M, MICHÁLEK J, BURIAN M, HÁJEK M, ZÁMEČNÍK J, JENDELOVÁ P, SYKOVÁ E: Acute and delayed implantation of positively charged HEMA scaffolds in spinal cord injury in the rat. J Neurosurg Spine 8: 745-751, 2008.

HULSEBOSCH CE: Recent advances in pathophysiology and treatment of spinal cord injury. Adv Physiol Educ 26: 238-255, 2002.

JENDELOVÁ P, HERYNEK V, URDZÍKOVÁ L, GLOGAROVÁ K., KROUPOVÁ J, ANDERSSSON B, BRYJA V, BURIAN M, HÁJEK M, SYKOVÁ E: Magnetic resonance tracking of transplanted bone marrow and embryonic stem cells labeled by iron oxide nanoparticles in rat brain and spinal cord. J Neurosci Res 76: 232243, 2004.

JENDELOVÁ P, LESNÝ P, HEJČL A, PŘÁDNÝ M, MICHÁLEK J, SYKOVÁ E: The implantation of biodegradable macroporous polymer hydrogels into the injured rat spinal cord. Exp Neurol 193: 248, 2005.

KAKULAS BA: Neuropathology: the foundation for new treatments in spinal cord injury. Spinal Cord 42: 549-563, 2004.

KATAOKA K, SUZUKI Y, KITADA M, OHNISHI K, SUZUKI K, TANIHARA M, IDE C, ENDO K, NISHIMURA Y.: Alginate, a bioresorbable material derived from brown seaweed, enhances elongation of amputated axons of spinal cord in infant rats. J Biomed Mater Res 54: 373-384, 2001.

KOPEN GC, PROCKOP DJ, PHINNEY DG: Marrow stromal cells migrate throughout forebrain and cerebellum, and they differentiate into astrocytes after injection into neonatal mouse brains. Proc Natl Acad Sci USA 96: 1071110716, 1999.

KWON BK, FISHER CG, DVORAK MF, TETZLAFF W: Strategies to promote neural repair and regeneration after spinal cord injury. Spine 30: 3-13, 2005.

LAVIK E, TENG YD, SNYDER E, LANGER R: Seeding neural stem cells on scaffolds of PGA, PLA, and their copolymers. Methods Mol Biol 198: 89-97, 2002.

LESNÝ P, DE CROOS J, PŘÁDNÝ M, VACÍK J, MICHÁLEK J, WOERLY S, SYKOVÁ E: Polymer hydrogels usable for nervous tissue repair. J Chem Neuroanat 23: 243-247, 2002.

LESNÝ P, MARTINOVÁ L, JENDELOVÁ P, JIRSÁK O, MICHÁLEK J, PŘÁDNÝ M, SYKOVÁ E: Utilizing nonwoven nanofiber materials as tissue replacements. Regen Med 2: 647, 2007.

LESNÝ P, BRYNDA E, MARTINOVÁ L, PǨÁDNÝ M, HOUSKA M, RIEDEL T, KYSILKA J, JENDELOVÁ P, JIRSÁK O, SYKOVÁ E: Polymers with modified surfaces for the treatment of spinal cord injury. $4^{\text {th }}$ Meeting of the International Society for Stem Cell Research, Toronto, 2006.

LESNÝ P, PŘÁDNÝ M, JENDELOVÁ P, MICHÁLEK J, VACÍK J, SYKOVÁ E: Macroporous hydrogels based on 2hydroxyethyl methacrylate. Part 4: Growth of rat bone marrow stromal cells in three-dimensional hydrogels with positive and negative surface charges and in polyelectrolyte complexes. J Mater Sci Mater Med 17: 829$833,2006$.

LI WJ, LAURENCIN CT, CATERSON EJ, TUAN RS, KO FK: Electrospun nanofibrous structure: a novel scaffold for tissue engineering. $J$ Biomed Mater Res 60: 613-621, 2002.

LOH NK, WOERLY S, BUNT SM, WILTON SD, HARVEY AR: The regrowth of axons within tissue defects in the CNS is promoted by implanted hydrogel matrices that contain BDNF and CNTF producing fibroblasts. Exp Neurol 170: 72-84, 2001.

MARCHAND R, WOERLY S, BERTRAND L, VALDES, N: Evaluation of two cross-linked collagen gels implanted in the transected spinal cord. Brain Res Bull 30: 415-422, 1993.

MARTINS A, ARAÚJO JV, REIS RL, NEVES NM: Electrospun nanostructured scaffolds for tissue engineering applications. Nanomed 2: 929-942, 2007.

MCKENZIE JL, WAID MC, SHI R, WEBSTER TJ: Decreased functions of astrocytes on carbon nanofiber materials. Biomaterials 25: 1309-1317, 2004. 
PITTENGER MF, MACKAY AM, BECK SC, JAISWAL RK, DOUGLAS R, MOSCA JD, MOORMAN MA, SIMONETTI DW, CRAIG S, MARSHAK DR: Multilineage potential of adult human mesenchymal stem cells: Science 284: 143-147, 1999.

NANDOE TRD, HURTADO A, LEVI AD, GROTENHUIS JA, OUDEGA M: Bone marrow stromal cells for repair of the spinal cord: towards clinical application. Cell Transplant 15: 563-577, 2006.

NICHOLSON C, SYKOVÁ E: Extracellular space structure revealed by diffusion analysis. Trends Neurosci 21: 207215, 1998.

PRANG P, MÜLLER R, ELJAOUHARI A, HECKMANN K, KUNZ W, WEBER T, FABER C, VROEMEN M, BOGDAHN U, WEIDNER N: The promotion of oriented axonal regrowth in the injured spinal cord by alginate-based anisotropic capillary hydrogels. Biomaterials 27: 3560-3569, 2006.

PROCKOP DJ: Marrow stromal cells as stem cells for nonhematopoietic tissues. Science 276: 71-74, 1997.

PROKOPOVÁ-KUBINOVÁ Š, VARGOVÁ L, TAO L, ULBRICH K, ŠUBR V, SYKOVÁ E, NICHOLSON C: Poly[N-(2-hydroxypropyl)methacrylamide] polymers diffuse in brain extracellular space with same tortuosity as small molecules. Biophys $J$ 80: 542-548, 2001.

PŘÁDNÝ M, PETROVICKÝ P, FROŇKOVÁ V, VACÍK J, SMETANA K, Jr.: Evaluation of biocompatibility of the copolymer of 2-hydroxyethyl methacrylate with 2-(methylsulfanyl) ethyl methacrylate. J Mater Sci Mater Med 13: 107-111, 2002.

PŘÁDNÝ M, LESNÝ P, FIALA J, VACÍK J, ŠLOUF M, MICHÁLEK J, SYKOVÁ E: Macroporous hydrogels based on 2-hydroxyethyl methacrylate. Part I. Copolymers of 2-hydroxyethyl methacrylate with methacrylic acid. Collect Czech Chem Commun 68: 812-822, 2003.

PŘÁDNÝ M, LESNÝ P, SMETANA K, Jr., VACÍK J, ŠLOUF M, MICHÁLEK J, SYKOVÁ E: Macroporous hydrogels based on 2-hydroxyethyl methacrylate. Part II. Copolymers with positive and negative charges, polyelectrolyte complexes. J Mater Sci Mater Med 16: 767-773, 2005.

PŘÁDNÝ M, MICHÁLEK J, LESNÝ P, HEJČL A, VACÍK J, ŠLOUF M, SYKOVÁ E: Macroporous hydrogels based on 2-hydroxyethyl methacrylate. Part 5: Hydrolytically degradable materials. J Mater Sci Mater Med 17: 13571364, 2006.

PŘÁDNÝ M, LESNÝ P, MARTINOVÁ L, MICHÁLEK J, SYKOVÁ E: Nonwoven polymeric nanofiber scaffolds utilizable for spinal cord injury repair. Drugs Future 32: 67, 2007.

QIU Q, SAYER M, KAWAJA M, SHEN X, DAVIES JE: Attachment, morphology, and protein expression of rat marrow stromal cells cultured on charged substrate surfaces. J Biomed Mater Res 42: 117-127, 1998.

ROCHKIND S, SHAHAR A, FLISS D, EL-ANI D, ASTACHOV L, HAYON T, ALON M, ZAMOSTIANO R, AYALON O, BITON IE, COHEN Y, HALPERIN R, SCHNEIDER D, ORON A, NEVO Z: Development of a tissue-engineered composite implant for treating traumatic paraplegia in rats. Eur Spine J 15: 234-245, 2006.

SOEKARNO A, LOM B, HOCKBERGER PE: Pathfinding by neuroblastoma cells in culture is directed by preferential adhesion to positively charged surfaces. Neuroimage 1: 129-144, 1993.

SUZUKI K, SUZUKI Y, OHNISHI K, ENDO K, TANIHARA M, NISHIMURA Y: Regeneration of transected spinal cord in young adult rats using freeze-dried alginate gel. NeuroReport 10: 2891-2894, 1999.

SUZUKI Y, KITAURA M, WU S, KATAOKA K, SUZUKI K, ENDO K, NISHIMURA Y, IDE C: Electrophysiological and horseradish peroxidase-tracing studies of nerve regeneration through alginate-filled gap in adult rat spinal cord. Neurosci Lett 318: 121-124, 2002.

SYKOVÁ E: Extrasynaptic volume transmission and diffusion parameters of the extracellular space. Neuroscience 129: 861-876, 2004.

SYKOVÁ E, JENDELOVÁ P: Magnetic resonance tracking of implanted adult and embryonic stem cells in injured brain and spinal cord. Ann N Y Acad Sci 1049: 146-160, 2005.

SYKOVÁ E, JENDELOVÁ P: Magnetic resonance tracking of transplanted stem cells in rat brain and spinal cord. Neurodegener Dis 3: 62-67, 2006.

SYKOVÁ E, JENDELOVÁ P: In vivo tracking of stem cells in brain and spinal cord injury. Prog Brain Res 16: 367383, 2007.

SYKOVÁ E, JENDELOVÁ P: Migration, fate and in vivo imaging of adult stem cells in the CNS. Cell Death Differ 14: 1336-1342, 2007. 
SYKOVÁ E, HOMOLA A, MAZANEC R, LACHMANN H, KONRÁDOVÁ SL, KOBYLKA P, PADR R, NEUWIRTH J, KOMRSKA V, VÁVRA V, ŠTULÍK J, BOJAR M: Autologous bone marrow transplantation in patients with subacute and chronic spinal cord injury. Cell Transplant 15: 675-687, 2006a.

SYKOVÁ E, JENDELOVÁ P, URDZÍKOVÁ L, LESNÝ P, HEJČL A: Bone marrow stem cells and polymer hydrogels-two strategies for spinal cord injury repair. Cell Mol Neurobiol 26: 1113-1129, $2006 \mathrm{~b}$.

TATOR CH: Update on the pathophysiology and pathology of acute spinal cord injury. Brain Pathol 5: 407-413, 1995.

TATOR CH: Experimental and clinical studies of the pathophysiology and management of acute spinal cord injury. J Spinal Cord Med 19: 206-214, 1996.

TATOR CH: Biology of neurological recovery and functional restoration after spinal cord injury. Neurosurgery 42 : 696-708, 1998.

TENG YD, LAVIK EB, QU X, PARK KI, OUREDNIK J, ZURAKOWSKI D, LANGER R, SNYDER EY: Functional recovery following traumatic spinal cord injury mediated by a unique polymer scaffold seeded with neural stem cells. Proc Natl Acad Sci USA 99: 3024-3029, 2002.

TSAI EC, DALTON PD, SHOICHET MS, TATOR CH: Matrix inclusion within synthetic hydrogel guidance channels improves specific supraspinal and local axonal regeneration after complete spinal cord transection. Biomaterials 27: 519-533, 2006.

URDZÍKOVÁ L, JENDELOVÁ P, GLOGAROVÁ K, BURIAN M, HÁJEK M, SYKOVÁ E: Transplantation of bone marrow stem cells as well as mobilization by granulocyte-colony stimulating factor promotes recovery after spinal cord injury in rats. J Neurotrauma 23: 1379-1391, 2006.

VANICKÝ I, URDZÍKOVÁ L, SAGANOVÁ K, ČǏŽKOVÁ D, GÁLIK J: A simple and reproducible model of spinal cord injury induced by epidural balloon inflation in the rat. J Neurotrauma 18: 1399-1407, 2001.

VASITA R, KATTI DS: Nanofibers and their applications in tissue engineering. Int J Nanomedicine 1: 15-30, 2006.

WICHTERLE O, LIM D: Hydrophilic gels for biological use. Nature 185: 117-118, 1960.

WOERLY S, CAVALLÉE C, MARCHAND R: Intracerebral implantation of ionic synthetic hydrogels. $J$ Neural Transplant Plast 3: 21-34, 1992.

WOERLY S, LAROCHE G, MARCHAND R, PATO J, ŠUBR V, ULBRICH K: Intracerebral implantation of hydrogel-coupled adhesion peptides: tissue reaction. J Neural Transplant Plast 5: 245-255, 1995.

WOERLY S, PINET E, DE ROBERTIS L, BOUSMINA M, LAROCHE G, ROITBACK T, VARGOVÁ L, SYKOVÁ E: Heterogeneous PHPMA hydrogels for tissue repair and axonal regeneration in the injured spinal cord. J Biomater Sci Polym Ed 9: 681-711, 1998.

WOERLY S, PETROV P, SYKOVÁ E, ROITBAK T, ŠIMONOVÁ Z, HARVEY AR: Neural tissue formation within porous hydrogels implanted in brain and spinal cord lesions: ultrastructural, immunohistochemical, and diffusion studies. Tissue Eng 5: 467-488, 1999.

WOERLY S, DOAN VD, EVANS-MARTIN F, PARAMORE CG, PEDUZZI JD: Spinal cord reconstruction using NeuroGel implants and functional recovery after chronic injury. $J$ Neurosci Res 15: 1187-1197, 2001 a.

WOERLY S, PINET E, DE ROBERTIS L, VAN DIEP D, BOUSMINA M: Spinal cord repair with PHPMA hydrogel containing RGD peptides (NeuroGel). Biomaterials 22: 1095-1111, $2001 \mathrm{~b}$.

YANG F, MURUGAN R, WANG S, RAMAKRISHNA S: Electrospinning of nano/micro scale poly(L-lactic acid) aligned fibers and their potential in neural tissue engineering. Biomaterials 26: 2603-2610, 2005.

YU X, DILLON GP, BELLAMKONDA RB: A laminin and nerve growth factor-laden three-dimensional scaffold for enhanced neurite extension. Tissue Eng 5: 291-304, 1999. 